University of Nebraska - Lincoln

DigitalCommons@University of Nebraska - Lincoln

Faculty Publications from the Harold W. Manter Laboratory of Parasitology

4-2008

\title{
New Genus and Species of Aporocotylidae (Digenea) from a Basal Actinopterygian, the American Paddlefish, Polyodon spathula, (Acipenseriformes: Polyodontidae) from the Mississippi Delta
}

\author{
Stephen A. Bullard \\ Auburn University, ash.bullard@auburn.edu \\ Scott D. Snyder \\ University of Nebraska at Omaha, sdsnyder@mail.unomaha.edu \\ Kirsten Jensen \\ University of Kansas \\ Robin M. Overstreet \\ Gulf Coast Research Laboratory, robin.overstreet@usm.edu
}

Follow this and additional works at: https://digitalcommons.unl.edu/parasitologyfacpubs

Part of the Parasitology Commons

Bullard, Stephen A.; Snyder, Scott D.; Jensen, Kirsten; and Overstreet, Robin M., "New Genus and Species of Aporocotylidae (Digenea) from a Basal Actinopterygian, the American Paddlefish, Polyodon spathula, (Acipenseriformes: Polyodontidae) from the Mississippi Delta" (2008). Faculty Publications from the Harold W. Manter Laboratory of Parasitology. 431.

https://digitalcommons.unl.edu/parasitologyfacpubs/431

This Article is brought to you for free and open access by the Parasitology, Harold W. Manter Laboratory of at DigitalCommons@University of Nebraska - Lincoln. It has been accepted for inclusion in Faculty Publications from the Harold W. Manter Laboratory of Parasitology by an authorized administrator of DigitalCommons@University of Nebraska - Lincoln. 


\title{
NEW GENUS AND SPECIES OF APOROCOTYLIDAE (DIGENEA) FROM A BASAL ACTINOPTERYGIAN, THE AMERICAN PADDLEFISH, POLYODON SPATHULA, (ACIPENSERIFORMES: POLYODONTIDAE) FROM THE MISSISSIPPI DELTA
}

\author{
Stephen A. Bullard, Scott D. Snyder ${ }^{\star}$, Kirsten Jensen†, and Robin M. Overstreet \\ Department of Coastal Sciences, University of Southern Mississippi, Gulf Coast Research Laboratory, 703 East Beach Drive, Ocean Springs, \\ Mississippi 39564.e-mail: ash.bullard@usm.edu
}

\begin{abstract}
Acipensericola petersoni n. gen., n. sp. (Digenea: Aporocotylidae) infects the heart of the American paddlefish Polyodon spathula (Walbaum, 1792) in the Mississippi Delta. It has robust, spike-like body spines arranged in ventrolateral transverse rows; a bowl-shaped anterior sucker centered on the mouth and having minute spines on the inner anteroventral surface only; a pharynx; an inverse U-shaped ceca extending to near the posterior body end; intercecal testes comprising a pre-ovarian testicular column plus a single testis posteriorly; an extensively lobed ovary located medially and immediately posterior to the testicular column; a spherical ootype that is intercecal and post-ovarian; a Laurer's canal; and a common genital pore. The new species is the first-named aporocotylid collected from a basal actinopterygian. It resembles the chondrichthyan aporocotylids Chimaerohemecus trondheimensis, Orchispirium heterovitellatum, and Hyperandrotrema cetorhini in having an inverse U-shaped ceca, but it is morphologically most similar to the anguilliform aporocotylid Paracardicoloides yamagutii in having that feature plus a comparable anterior sucker, a single testis posteriorly, an intertesticular ovary, and a common genital pore. Sequence data for the complete small subunit ribosomal DNA (18S) do not refute its membership within Aporocotylidae nor its affinity to 1 of those aforementioned aporocotylids: A. petersoni was basal to the few teleost aporocotylids analyzed, and C. trondheimensis was the only taxon basal to A. petersoni. We regard the specimens of Spirorchis sp. previously reported from the shortnose sturgeon Acipenser brevirostrum Lesueur, 1818 as congeneric with the new species.
\end{abstract}

Adult blood flukes (Digenea: Schistosomatoidea) infect jawed vertebrates (Gnathostomata) and historically have been grouped into 3 families correlating to the broad phylogenetic affiliations of their definitive host groups: Aporocotylidae Odhner, 1912 for those blood flukes that infect non-tetrapod gnathostomes, i.e., fishes (Smith, 1997a, 1997b, 2002); Spirorchiidae Stunkard, 1921 for those of turtles (Platt, 2002); and Schistosomatidae Stiles and Hassall, 1898 for those of birds and mammals (Khalil, 2002). We concur with Stunkard (1921) who stated that, "In my opinion, the Aporocotylidae of fishes, the Spirorchidae of turtles, and the Schistosomatidae of birds and mammals constitute a well-defined group with inherent natural relationships." At present, Aporocotylidae includes only 5 nominal species that infect cartilaginous fishes (Chondrichthyes) (Bullard et al., 2006), plus $>100$ species that infect bony fishes (Actinopterygii: Teleostei) (see Smith, 1997a, 1997b). As such, aporocotylids infect definitive hosts allocated to widely separated gnathostome lineages, whereas all adult spirorchiids and schistosomatids are reportedly restricted to members of Tetrapoda (Gnathostomata: Sarcopterygii). Although Aporocotylidae is the most diverse blood fluke family, with respect to the number of named species and accepted genera, at least tens of aporocotylid species remain unnamed (S. Bullard, unpubl.), and many potential host lineages seem vastly under-explored for the presence of aporocotylid infections. Fewer than 200 (Smith, $1997 b$ ) of the nearly 28,000 valid fish species (Nelson, 2006) are reported as hosts, and most fish orders (46 of 63) reportedly lack infections. This void of information is a barrier to understanding the relationship between host ancestry and the evolution of fish blood flukes. Most notable among those under-explored host lineages are the lower (basal) actinopterygians (sensu Grande and Bemis, 1996), which form a non-monophyletic

Received 14 May 2007; revised 16 August 2007; accepted 16 August 2007.

* Department of Biology, University of Nebraska at Omaha, Omaha, Nebraska 68182.

$\uparrow$ Department of Ecology and Evolutionary Biology, University of Kansas, Lawrence, Kansas 66045. group of convenience that includes extant members allocated to 2 distinct lineages, i.e., Acipenseriformes (including paddlefishes [Polyodontidae] and sturgeons [Acipenseridae]) and Polypteriformes (including bichirs [Polypteridae] only) (e.g., Grande and Bemis, 1996; Nelson, 2006). Herein, we provide the first name and description for an aporocotylid that infects a basal actinopterygian, the American paddlefish Polyodon spathula (Walbaum, 1792) (Acipenseriformes: Polyodontidae) and propose a new genus to accommodate this new species.

\section{MATERIALS AND METHODS}

American paddlefish from the Mississippi Delta were captured with gill nets in April of 2004 and 2006. All fish were killed by spinal severance, and immediately afterwards the heart was extracted, placed in a sample bag, bisected to expose its lumen, immersed in an anticoagulant solution of $\sim 5.0 \mathrm{gm} \mathrm{NaCl}$ and $\sim 2.0 \mathrm{gm} \mathrm{NaCl}$-citrate/L of distilled water, and kept in a cooler with a small amount of ice for several hours. Upon returning to the laboratory, the contents of the bag were examined with the aid of a dissecting microscope. Observations of living flukes were made with the aid of dissecting and compound microscopes. Flukes intended as whole mounts were killed with heat from an ethanol-burner flame, under little or no coverslip pressure, and transferred to a vial of $5 \%$ neutral buffered formalin (n.b.f.). Whole mounts were stained in Van Cleave's hematoxylin with several additional drops of Ehrlich's hematoxylin, made basic at 70\% ethanol with lithium carbonate and butyl-amine, dehydrated, cleared in clove oil, and mounted in Canada balsam. Two specimens were embedded in paraffin, seriallysectioned at $4 \mu \mathrm{m}$, and stained with Gill's hematoxylin and eosin. Three specimens for scanning electron microscopy (SEM) were dehydrated, immersed in hexamethyldisilazane for $30 \mathrm{~min}$, air-dried for $45 \mathrm{~min}$, and sputter-coated with gold-palladium. Drawings were made with the aid of a drawing tube and facilitated by differential interference contrast (DIC) optical components. Measurements are reported in $\mu \mathrm{m}$ and given as ranges with the sample size in parentheses. The specimen of "Spirorchis sp." of Appy and Dadswell (1978) (USNPC No. 73138) was lost and presumably destroyed during Hurricane Katrina on 29 August 2005 .

Fish classification and higher level taxon names used herein follow primarily Grande and Bemis (1996) and Nelson (2006). Because "fishes" comprise a paraphyletic assemblage if one excludes Tetrapoda, we herein use that term not as a taxonomic rank but rather, as stated by Nelson (2006), "as a matter of convenience, essentially to describe 
those vertebrates studied by ichthyologists and covered in ichthyological courses.'

The specimens intended for molecular analyses were fixed directly in $95 \% \mathrm{EtOH}$, and genomic DNA was extracted using a DNeasy tissue kit (Qiagen, Valencia, California) according to the manufacturer's instructions. Polymerase chain reaction (PCR) was used to amplify SSU rDNA with the forward primer 18SE (5'-CCG AAT TCG TCG ACA ACC TGG TTG ATC CTG CCA GT) and the reverse primer WORMB (5'-CTT GTT ACG ACT TTT ACT TCC) (Littlewood and Olson, 2001). Reactions were performed in a total volume of $25 \mu \mathrm{l}$ and consisted of approximately $20 \mathrm{ng}$ of gDNA, $0.2 \mu \mathrm{M}$ of each primer, and $12.5 \mu$ l FideliTaq PCR Master Mix (USB Corporation, Cleveland, Ohio). Reaction volume was brought to $25 \mu \mathrm{l}$ with sterile deionized water. Amplification was performed on a Perkin Elmer GeneAmp 2400 thermocycler (Perkin Elmer, Waltham, Massachusetts) under the following conditions: $94 \mathrm{C}$ for $4 \mathrm{~min}$, followed by 40 cycles of $94 \mathrm{C}$ for 30 sec, $50-56 \mathrm{C}$ for $30 \mathrm{sec}$, and $72 \mathrm{C}$ for $2 \mathrm{~min}$, followed by 1 cycle of $72 \mathrm{C}$ for $5 \mathrm{~min}$. Unincorporated PCR primers and nucleotides were removed from PCR products using exonuclease I and shrimp alkaline phosphatase from a PCR Product Pre-Sequencing Kit (USB Corporation). Sequences were determined directly from PCR templates using Big Dye terminator chemistry and an ABI Prism 3100 (Applied Biosystems, Forest City, California). Primers used in sequencing SSU rDNA included the PCR primers and the internal forward primers $388 \mathrm{~F}$ (5'-AGG GTT CGA TTC CGG AG) and 1100F (5'-CAG AGT TTC GAA GAC GAT C) and the reverse primers CEST1R (5'-TTT TTC GTC ACT ACC TCC CC) and 1270R (5'-CCG TCA ATT CCT TTA AGT) (Littlewood and Olson, 2001). Sequence data from the new species were aligned with sequences taken from GenBank. The ingroup consisted of the new species (GenBank DQ534192), Aporocotyle spinosicanalis (AY222177), Neoparacardicola nasonis (AY222097), Plethorchis acanthus (AY222096), and Chimaerohemecus trondheimensis (AY157213). The sequence for Sanguinicola cf. inermis (AY22098) was included, although the identity of this species needs clarification because the DNA was extracted from a cercaria rather than from an adult specimen. Outgroups were selected from basal non-aporocotylid digeneans (sensu Snyder, 2004) and included Alaria alata (AY222091) and Cardiocephaloides longicollis (AY222089). Sequences were assembled using Contig Express (v. 8.0, InforMax, Invitrogen, Carlsbad, California) and provisionally aligned using Clustal W (Thompson et al., 1994), followed by alignment by eye in MacClade v. 4.06 (Sinauer and Associates, Sunderland, Massachusetts) (Maddison and Maddison, 2003) Positions for which alignment was ambiguous were removed before analysis. Maximum parsimony analysis of these data was performed using the "branch and bound search," "random sequence addition," and "TBR branch-swapping" options of PAUP* (v. 4.0b10, Sinaur and Associates) (Swofford, 2001). Gaps were treated as missing data, and characters were unordered with equal weight. Nodal support was assessed using bootstrap resampling (Felsenstein, 1985) (1,000 bootstrap replicates, 100 heuristic searches/replicate).

\section{DESCRIPTION}

\section{Acipensericola n. gen.}

$$
\text { (Figs. 1-28) }
$$

Diagnosis: Body flat, ventrally concave, elongate, $<4$ times longer than wide, with anterior and posterior ends tapering approximately equally, spined; tegumental body spines robust, spike-like, lacking recurved tip, in ventrolateral transverse rows. Rosethorn-shaped spines absent. Lateral nerve cord extending nearly entire body length, appearing subterminal in anterior body end, with commissure anteriorly. Dorsolateral nerve cords indistinct. Sensory papillae abundant, occupying ventrolateral body surface between lateral nerve cord and body margin. Anterior sucker bowl-shaped, centered on mouth, demarcated from the anterior body end by peduncle, having minute spines on inner anteroventral surface only. Pharynx between anterior sucker and nerve commissure, highly muscular, intensely basophilic. Esophagus medial, straight, ventral to anterior nerve commissure, extending posteriad approximately $1 / 6$ of body length; posterior esophageal swelling present immediately anterior to cecal bifurcation. Intestine inverse U-shaped, with long posterior ceca only and no anterior cecum, smooth, lacking diverticula or secondary rami, extending posteriad to near body end Testes intercecal, non-contiguous, an anterior testicular column plus 1 testis posteriorly, with extensively lobed margins. Cirrus sac clearly delineated from surrounding tissue, enveloping seminal vesicle, prostatic gland cells, and cirrus; cirrus everting dorsally near dextral body margin; prostatic gland cells spheroid, encircling ejaculatory duct at base of cirrus and proximal to common genital pore. Ovary single, medial, intercecal, separating anterior column of testes from single posterior testis, immediately posterior to testicular column, deeply lobed, located within posterior $1 / 4$ of body. Oviduct sinistral, functioning as oviducal seminal receptacle. Vitellarium an extensive network of narrow, interconnecting branching bands, situated both dorsal and ventra to gonads and ceca, not extending laterally beyond ventrolateral nerve cords. Laurer's canal present. Ootype spherical, intercecal, inter-testicular, post-ovarian, medial to cirrus sac. Uterus near ovarian level, intercecal, typically containing several large eggs; uterine eggs oblong, $>1 / 3$ the width of uterus and appearing markedly collapsed or compressed in whole mounts. Metraterm indistinct. Male and female reproductive tracts sharing common opening, lacking posterolateral protuberance of body associated with pore. Excretory vesicle large, Y-shaped, cradling posterior testis, thin-walled. In blood vascular system of members of Acipenseriformes.

Differential diagnosis: Body elongate, $<4$ times longer than wide; tegumental body spines robust, spike-like, lacking recurved tip, in ventrolateral transverse rows. Rosethorn-shaped spines absent. Anterior sucker bowl-shaped, centered on mouth, demarcated from the anterior body end by peduncle, having minute spines on inner anteroventral surface only. Pharynx highly muscular, intensely basophilic. Posterior esophageal swelling present. Intestine inverse U-shaped and lacking anterior ceca. Testes intercecal, an anterior testicular column plus 1 testis posteriorly. Cirrus sac enveloping seminal vesicle, prostatic gland cells, and cirrus; cirrus everting dorsally near dextral body margin; posterolateral protuberance associated with male genital pore lacking. Ovary single, medial, intercecal, intertesticular. Oviduct sinistral, functioning as oviducal seminal receptacle. Laurer's canal present. Ootype spherical. Male and female reproductive tracts sharing common opening, lacking posterolateral protuberance of body associated with pore.

Type species: Acipensericola petersoni $\mathrm{n}$. sp. Other species: Acipensericola sp. (as Spirorchis sp. of Appy and Dadswell [1978]).

\section{Remarks}

The new genus resembles the monotypic genera Chimaerohemecus van der Land, 1967, Orchispirium Madhavi and Rao, 1970, Hyperandrotrema Maillard and Ktari, 1978, and Paracardicoloides Martin, 1974, in having inverse U-shaped ceca. It also has affinities to both Chimaerohemecus and Hyperandrotrema by having a Laurer's canal, not present, or at least not reported, in any other aporocotylid genera. Acipensericola, however, is most similar to Paracardicoloides because it has a comparable anterior sucker (oral disc of Martin [1974]), a separate testis posteriorly, an intertesticular ovary, and a common genital pore. It is noteworthy that the ventrolateral nerve cords of both A. petersoni and Paracardicoloides yamagutii Martin, 1974 appear subterminal, i.e., they are blind-ending in the anterior end of the body posterior to the level of the mouth. Acipensericola is easily differentiated from these and all other aporocotylid genera in having a large, bowlshaped anterior sucker with minute spines on the inner anteroventral surface only (Figs. 1, 7, 12, 19) and an obvious, highly muscular pharynx (Figs. 1, 7, 12). In addition to that combination of features, the shape and orientation of the ventrolateral body spines differentiates the new genus. It has ventrolateral body spines that are spike-like and arranged in distinct transverse rows (Fig. 2). Chimaerohemecus and $\mathrm{Hy}$ perandrotrema each have 1 or 2 ventrolateral columns of C-shaped body spines (Van der Land, 1967; Maillard and Ktari, 1978; Bullard et al., 2006), Paracardicoloides has straight body spines that are distributed in a narrow ventrolateral field (Martin, 1974; Nolan and Cribb, 2004), and Orchispirium lacks spines altogether (Madhavi and Rao, 1970). None of the remaining accepted genera of Aporocotylidae, all of which comprise species that infect bony fishes (Teleostei) only, have a bowl-shaped anterior sucker, strongly muscular pharynx, inverse U-shaped ceca, or Laurer's canal.

\section{Acipensericola petersoni $\mathrm{n}$. sp.} (Figs. 1-28)

Diagnosis of adult (measurements and illustrations based on 10 whole mounted specimens, 2 serially-sectioned specimens, and 3 SEM 

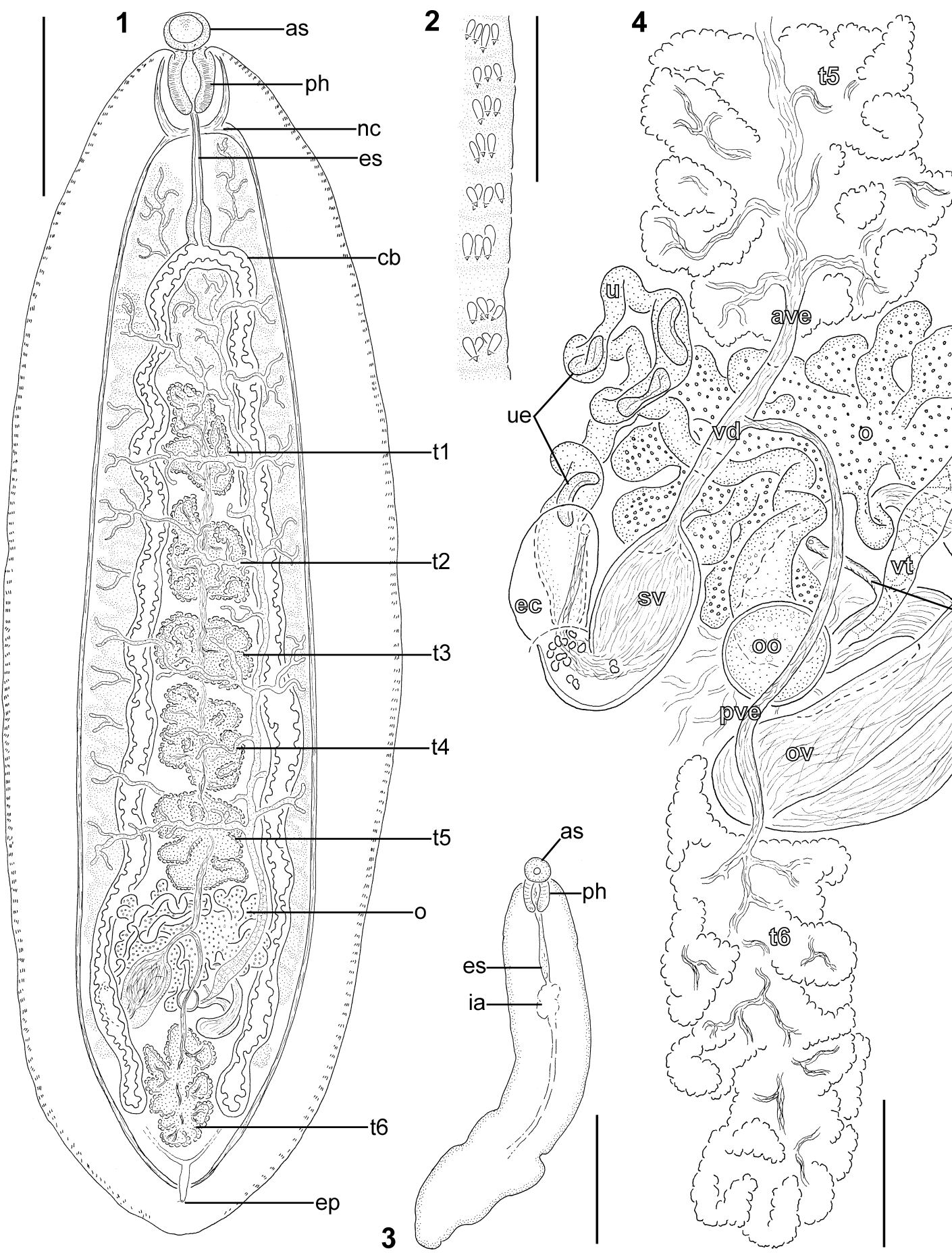

1 

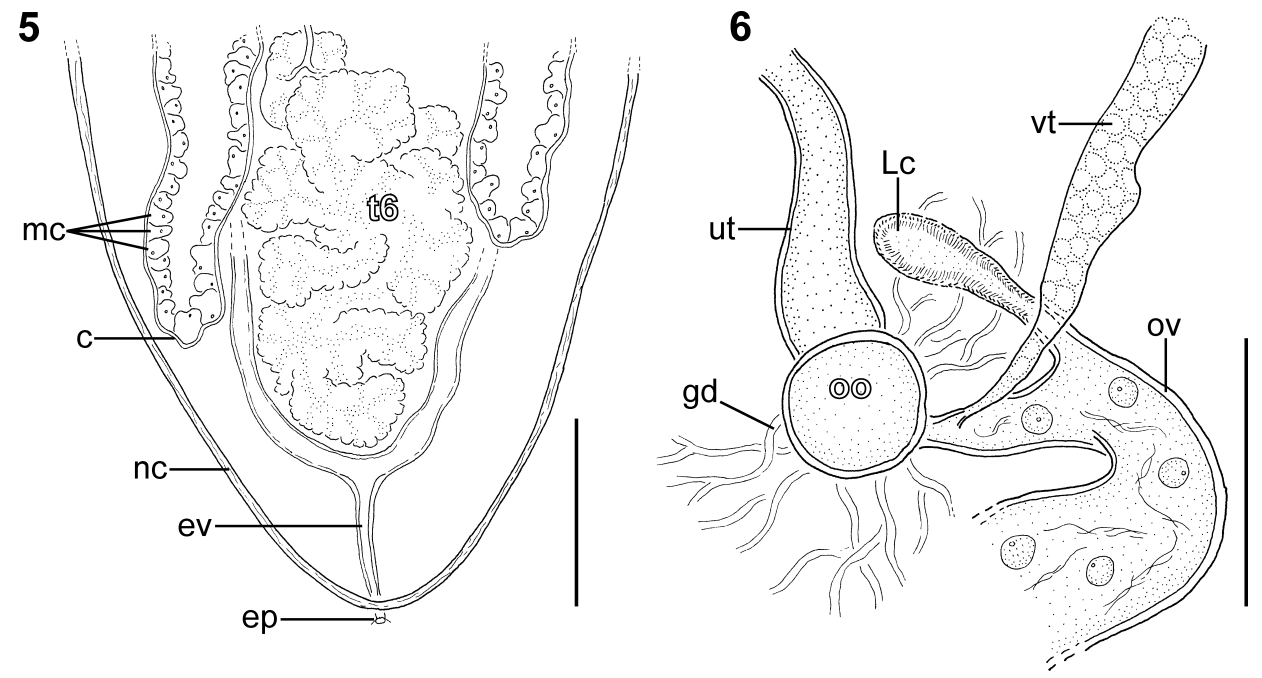

FIGURES 5-6. Acipensericola petersoni from the heart of Polyodon spathula, ventral view. (5) Posterior body end of paratype showing posteriormost testis (t6), mononucleate cells (mc) of cecal wall, distal end of dextral cecum (c), nerve cord (nc), excretory vesicle (ev), and dorsal, subterminal excretory pore (ep). Bar $=200 \mu \mathrm{m}$. (6) Paratype showing junction of Laurer's canal (Lc), vitelline duct (vt), and oviduct (ov). Ootype (oo), glandular ducts (gd), and proximal portion of uterus (ut). Bar $=100 \mu \mathrm{m}$.

end (Figs. 1, 5); ventrolateral nerve commissure 139-273 (9) or 5-8\% of body length from anterior body end, 64-140 (9) across width of worm, 20-35 (7) in diameter, perpendicular to midline of body (Fig. 1). Ventral sensory papillae 5-12 (10) in diameter, appearing volcanoshaped with light microscopy (Fig. 11) and nipple-like with SEM (Figs. $18,20,23)$, arranged in ventrolateral bands, delimited by approximate track of ventrolateral nerve cord and lateral body margin (Figs. 18, 23), indistinct or absent along midline of ventral and dorsal body surface. Anterior sucker 75-159 (9) in diameter or 9-13\% of body width (Figs. $1,7,12,18,19,21,22,25)$; anterior sucker spines about 3-5 long, conical, directed posteriorly, clustered, not occurring in clearly delineated rows (Figs. 24, 26, 27). Pharynx 139-199 (10) long or 38-53\% of esophagus length, 109-144 (10) wide or 4-11 times esophagus width, with muscular wall 30-55 (10) thick, nearly as thick as anterior body end (Figs. 1, 7, 12). Esophagus 273-497 (10) long or 10-14\% of body length, 10-25 (10) wide, with wall 5-10 (10) thick at level immediately posterior to pharynx; posterior swelling 40-100 (10) wide or 2-7 times width of anterior esophagus at level immediately posterior to pharynx, 104-224 (10) long or 31-67\% of esophagus length, with wall 15-35 (10) thick (Figs. 1, 13). Esophageal gland indistinct surrounding swelling. Ceca bifurcating immediately posterior to esophageal swelling, 388-647 (10) or 14-19\% of body length from anterior body end, extending posteriad in parallel $1,792-2,995$ (10) or $72-79 \%$ of body length, ending $259-408$ (10) or 9-13\% of body length from posterior body end, 40-135 (10) wide, not extending laterally beyond ventrolateral nerve cord (Figs. 1,3), with wall having cuboid basophilic mononucleate cells (Figs. 5, 14), containing granular material within lumen in some individuals; granular material blackish, probably comprising hematin and other compounds formed in decomposition of hemoglobin and erythrocytes, nearly filling cecal lumen in some specimens (Figs. $8,10)$.

Testes spheroid, 6 in number, each approximately equal in diameter, comprising 5 testes (t1-t5) oriented in a single testicular column plus 1 separate testis (t6) posteriorly; testicular column intercecal, 933-1,743 (10) long or $35-50 \%$ of body length, with anterior-most testis in column $221-565$ (10) or $9-21 \%$ of body length from cecal bifurcation, 173393 (10) wide or $20-32 \%$ of body width at widest level; posterior-most testis intercecal, between distal ends of ceca, 259-512 (10) long or 9$13 \%$ of body length, 114-299 (10) wide or $11-24 \%$ of body width, $313-597$ (10) or $11-16 \%$ of body length from posterior margin of an-
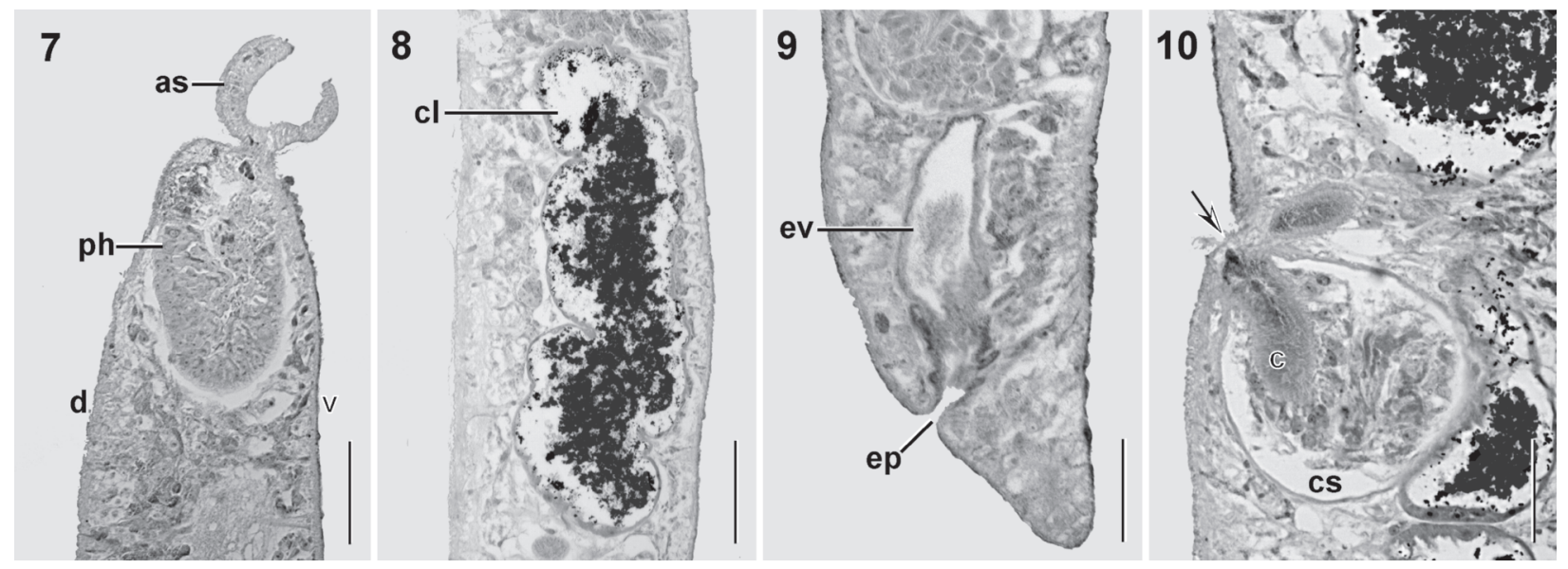

FiguREs 7-10. Acipensericola petersoni from the heart of Polyodon spathula, adult, longitudinal sections. (7) Anterior region showing anterior sucker (as) and pharynx (ph). Dorsal (d) and ventral (v) surfaces. Bar $=50 \mu \mathrm{m}$. (8) Blackish residue, probably partially-digested blood components, occupying the cecal lumen (cl). Bar $=50 \mu \mathrm{m}$. (9) Posterior end showing excretory vesicle (ev) and subterminal excretory pore (ep) opening on dorsal surface. Bar $=50 \mu \mathrm{m}$. (10) Terminal genitalia showing common genital pore (arrow), cirrus (c), and cirrus sac (cs). Bar $=25 \mu \mathrm{m}$. 

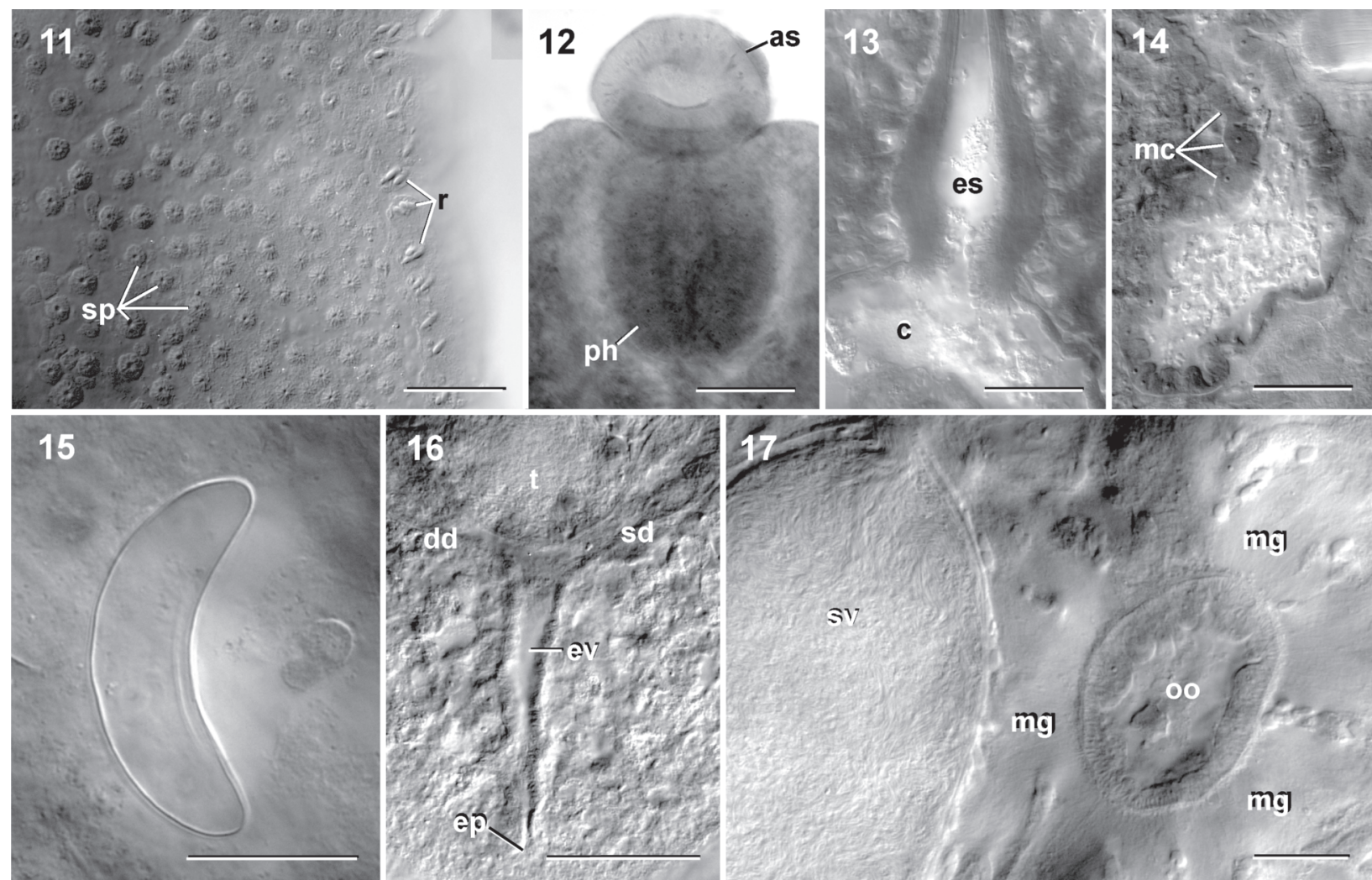

FiguRES 11-17. Acipensericola petersoni from the heart of Polyodon spathula, ventral view, light micrographs. (11) Anterior ventrolateral surface showing sensory papillae (sp) and several transverse rows (r) of ventrolateral body spines, paratype. Bar $=30 \mu \mathrm{m}$. (12) Anterior sucker (as) and pharynx (ph) of paratype. Bar $=60 \mu \mathrm{m}$. (13) Posterior esophageal swelling (es) immediately anterior to cecal bifurcation (c), paratype. Bar $=30 \mu \mathrm{m}$. (14) Distal end of dextral cecum showing large, basophilic mononucleate cells (mc) of cecal wall. Bar $=60 \mu \mathrm{m}$. (15) Egg ejected from uterus, paratype. Note the thin egg shell that lacks an operculum. Bar $=20 \mu \mathrm{m}$. (16) Posterior end of paratype showing Y-shaped terminal excretory features immediately posterior to posterior testis (t); excretory vesicle (ev) and pore (ep) plus dextral (dd) and sinistral (sd) collecting ducts. Bar $=35 \mu \mathrm{m}$. (17) Ootype (oo) and surrounding glandular ducts of Mehlis' gland (mg) adjacent to proximal region of seminal vesicle (sv), paratype. Bar $=25 \mu \mathrm{m}$.

terior testicular column; post-testicular space 144-259 (10) or 5-8\% of body length (Figs. 1, 3). Vasa efferentia an interconnecting meshwork of fine ducts entwining throughout testicular tissue, containing sperm in all specimens, with anterior and posterior trunks linking testicular column and posterior-most testis (Figs. 1, 4), difficult to trace in fixed specimens; anterior trunk of vasa efferentia 14-174 (4) long, extending posteriad from posterior margin of $\mathrm{t} 5$ and curving dextrad before uniting with posterior trunk, 10-17 (4) wide (Fig. 4); posterior trunk of vasa efferentia extending 224-373 (4) or 7-12\% of body length from anterior margin of t6 before uniting with anterior trunk and forming vas deferens, 5-12 (4) wide (Fig. 4); vas deferens dextral, 40-99 (6) long, 5-27 (6) wide, extending a short distance dorsolaterally before joining with cirrus sac and seminal vesicle, containing sperm in all specimens (Fig. 4). Cirrus sac thin-walled, enclosing seminal vesicle and glandular cells (Figs. 4, 10); seminal vesicle ovoid, between t5 and t6, not extending laterally beyond dextral ventrolateral nerve cord, 99-273 (9) long, 59131 (9) wide or 1.7-2.4 times longer than wide, orienting toward dextral body margin, containing sperm in all specimens; extruded cirrus dorsal, dextral, 65-99 (2) long, 30-50 (5) wide, directing anteriad, finger-like, lacking spines; post-cirrus sac space 475-811 (10) long or 17-23\% of body length.

Ovary 189-448 (10) long or 8-10\% of body length, 213-472 (10) wide or $26-41 \%$ of body width, $0.9-1.5$ times wider than long, dorsa to vas deferens and seminal vesicle; post-ovarian space 465-870 (10) long or $17-24 \%$ of body length (Fig. 4). Oviduct sinuous, ultimately extending posteriad while curving mediad, recurving dorsally at anterior margin of t6, extending anteriad while curving toward midline, containing sperm for entire length, 25-99 (7) in maximum width (Fig. 4). Laurer's canal extending 74-136 (7) anteromedially from distal region of oviduct, immediately before union of vitelline duct and oviduct, opening on dorsal surface, 7-10 (7) wide, highly glandular. Primary vitelline collecting duct sinistral, ventral, extending posteriad and following a track between or ventral to testicular column and intestinal cecum, extending 174-448 (9) posteriad from margin of t5, uniting with oviduct immediately before joining ootype and short distance distal to where Laurer's canal joined (Figs. 1, 4, 6). Ootype 45-69 (9) in diameter, medial, at level of cirrus sac, anterior to major posterior loop of oviduct, dorsal to vasa efferentia (Figs. 1, 5, 17); Mehlis' gland diffuse, surrounding ootype, with many hair-like ducts (Fig. 17). Uterus primarily dextral for most of length, running anteriad a short distance along midline from ootype, ventral to ovary, dorsal to vas deferens, becoming somewhat convoluted lateral to ovary, looping anteriad before running posteriad, 20-37 (10) in maximum width (Figs. 1, 4). Uterine eggs 35-50 (7) long, large relative to many other aporocotylids, curved, crenulated, or collapsed completely in many specimens, lacking apparent operculum, with thin membranous shell when in distal portion of uterus (Fig. 4); ejected eggs seemingly more regular in shape (Fig. 15); mature egg in gill of definitive host not observed.

Excretory vesicle oblong, 71-146 (9) long, 10-32 (9) wide; excretory pore subterminal, dorsal, 42-128 (9) or 2-3\% of body length from posterior body end (Figs. 1, 5, 9, 16); system difficult to observe in fixed specimens.

Diagnosis of juvenile (based on 1 whole mounted specimen from heart): Body 663 long, 98 wide; ventrolateral body spines indistinct. Nervous system indistinct. Sensory papillae not evident. Anterior sucker 35 in diameter. Pharynx 60 long, 40 wide. Esophagus 102 long or 15\% of body length, 8 wide immediately posterior to pharynx, extending directly posteriad; posterior esophageal swelling 28 long, 12 wide. 

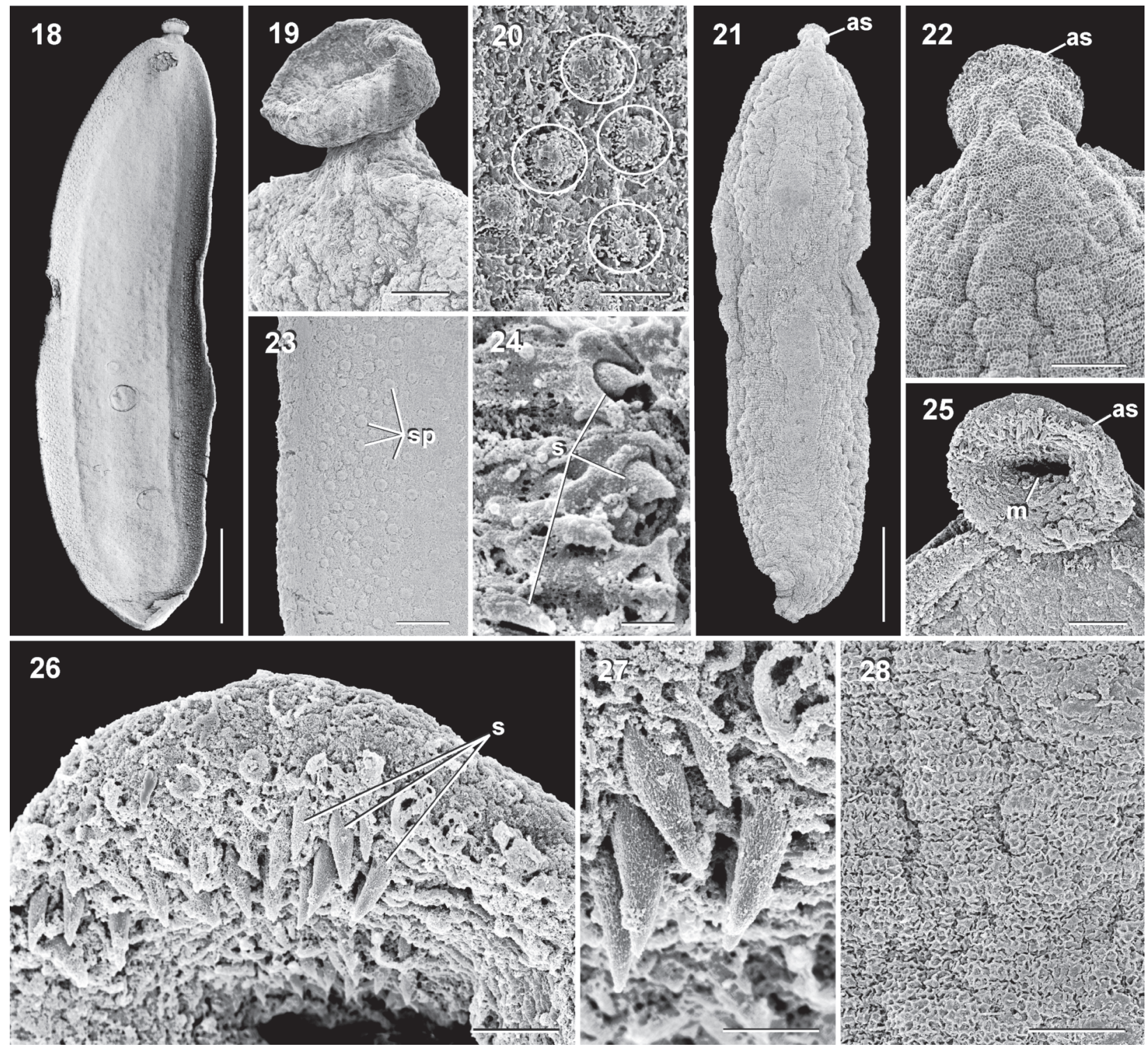

FiguRES 18-28. Acipensericola petersoni from the heart of Polyodon spathula, adult specimens, scanning electron micrographs. (18) Body, ventral view. $B a r=100 \mu \mathrm{m}$. (19) Ventral aspect of anterior sucker, lateral view. Bar $=10 \mu \mathrm{m}$. (20) Sensory papillae (circled) on ventral surface of body. Bar $=5 \mu \mathrm{m}$. (21) Body, dorsal view. Anterior sucker (as). Bar $=100 \mu \mathrm{m}$. (22) Anterior sucker (as), dorsal view. Bar $=100 \mu \mathrm{m}$. (23) Ventrolateral surface of body showing dispersion of sensory papillae (sp). Bar $=10 \mu \mathrm{m}$. (24) Spine row showing protruding tips of ventrolateral body spines (s). Bar $=0.5 \mu \mathrm{m}$. (25) Anterior sucker (as) and mouth $(\mathrm{m})$, ventral view. Bar $=10 \mu \mathrm{m}$. (26) Higher magnification of Figure 25 showing anterior sucker spines (s). Bar $=4 \mu \mathrm{m}$. (27) Higher magnification of Figure 26 showing cluster of spines on the inner anteroventral surface of the anterior sucker. Bar $=2 \mu \mathrm{m}$. (28) Tegument of body, dorsal view. Bar $=10 \mu \mathrm{m}$.

Esophageal gland indistinct. Cecal anlagen appearing as a sac-like medially-positioned mass (Fig. 3). Terminal genitalia, gonads, and excretory system not evident.

\section{Taxonomic summary}

Type and only known host: Polyodon spathula (Walbaum, 1792) (Acipenseriformes: Polyodontidae), the American paddlefish.

Sites: Adults and juvenile in atrium, ventricle, and bulbous arteriosus of heart.

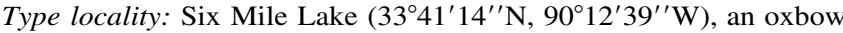
of the Tallahatchie River near Greenwood, Mississippi. Other locality: Lower Lake $\left(34^{\circ} 24^{\prime} 26^{\prime \prime} \mathrm{N}, 89^{\circ} 43^{\prime} 12^{\prime \prime} \mathrm{W}\right)$, a tailrace comprising the upper portion of the Little Tallahatchie River exiting Sardis Lake Reservoir, near Batesville, Mississippi.

Specimens deposited: Holotype USNPC No. 100676. Paratypes USNPC Nos. 100677-100678.
Prevalence of infection: Nine of $11(82 \%)$ from Six Mile Lake and 6 of $6(100 \%)$ from Lower Lake.

Etymology: The specific name 'petersoni' honors Jody Lee Peterson (Parasitology Section, Gulf Coast Research Laboratory) for his intuition and skill as a fisherman and for his invaluable field assistance to SAB during 1997 through 2007.

\section{Remarks}

Live specimens of Acipensericola petersoni used their flat, ventrallyconcave surface and their ventrolateral body spines for attachment and locomotion. Like some other crawling aporocotylids that have been observed (Bullard and Overstreet, 2002, 2003, 2004), these flukes adhere to the walls of the heart, as well as to glass and plastic surfaces, by using the lateral body margin, presumably as a gasket that creates and maintains an internal negative pressure between the fluke's body and the attachment surface. Specimens crawled by repeated, wave-like un- 


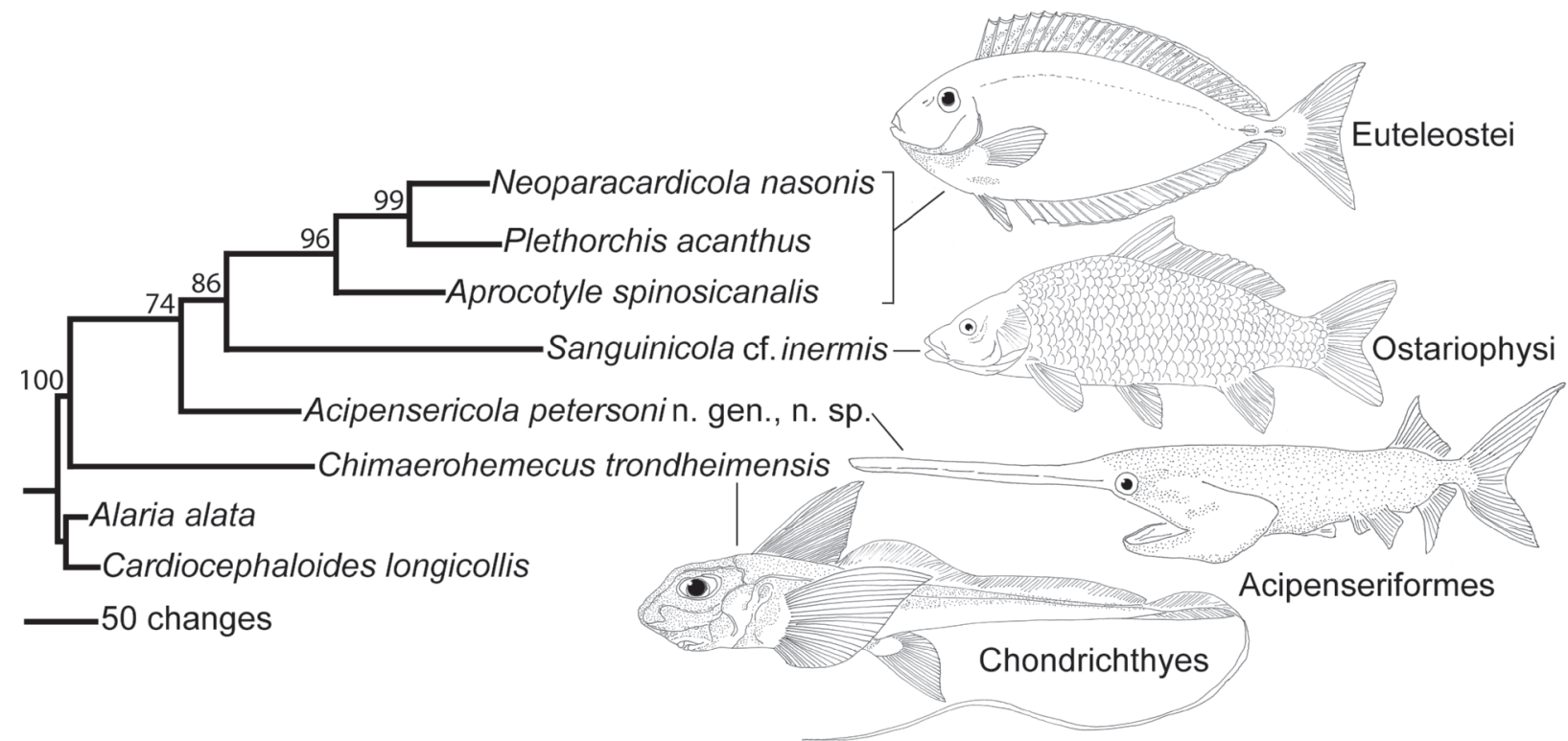

FIGURE 29. Phylogram based on maximum parsimony analysis of small subunit ribosomal DNA. Nodal support based on bootstrap resampling is to the left of each ingroup node. Note that the aporocotylids infecting Chondrichthyes (Chimaerohemecus trondheimensis), Acipenseriformes (Acipensericola petersoni), and Ostariophysi (Sanguinicola cf. inermis) are basal to those aporocotylids that infect Euteleostei (Aporocotyle spinosicanalis, Plethorchis acanthus, and Neoparacardicola nasonis).

dulations of the lateral body margins. As with adults of some species of Cardicola, as well as with Elaphrobates euzeti Bullard and Overstreet, 2003, the transverse rows of ventrolateral body spines of A. petersoni probably enhance grip and traction for attaching to, and crawling over, uneven fleshy surfaces. However, these spines apparently are not required for initial attachment and crawling since adults adhered to, and crawled over, impervious surfaces, e.g., glass and plastic, and the juvenile specimen lacked spines altogether (Fig. 3). Regarding the function of the anterior sucker, a few live specimens applied their anterior sucker to the surface of the plastic sample bag and remained anchored there, even after the bag was shaken vigorously. These specimens, however, could be dislodged by inserting the bristles of an artist's brush beneath the rim of the anterior sucker.

Parsimony analysis of SSU data (Fig. 29) derived from a single specimen of A. petersoni, as well as from several other aporocotylids, produced a single most-parsimonious tree with nodal support ranging from 74-100 and a tree length of 1,311 (224 of the 1,815 total base pairs sequenced were informative). The tree topology showed that $C$. trondheimensis, a chondrichthyan blood fluke, was the most basal ingroup taxon in the tree, with A. petersoni basal to Sanguinicola $\mathrm{cf}$. inermis, both of which were basal to 3 euteleost (Euteleostei) aporocotylids included in the analysis, i.e., Aporocotyle spinosicanalis, Plethorchis acanthus, and Neoparacardicola nasonis.

\section{DISCUSSION}

At least 1 species of the new genus infects a sturgeon in North America. This reported (Appy and Dadswell, 1978), previously collected, but unnamed aporocotylid infects the mesenteric vessels of shortnose sturgeon (Acipenser brevirostrum Lesueur, 1818 [Acipenseridae]) in the Saint John River Estuary, New Brunswick, Canada. Appy and Dadswell (1978) detailed 9 immature specimens and identified the specimens as Spirorchis sp.; however, we regard the unnamed species as congeneric with $A$. petersoni because it has: (1) a prominent, bowl-shaped anterior sucker that is centered on the mouth; (2) a clearly delineated pharynx that is located immediately posterior to the anterior sucker; (3) an inverse U-shaped ceca that extends to near the posterior body end; (4) a testicular column; and (5) ventrolateral body spines. Although ventrolateral body spines were neither described nor illustrated by Appy and Dadswell (1978), we examined a voucher specimen (USNPC No. 73138) and confirmed the presence of ventrolateral spines. However, since we could not discern ventrolateral body spines in the juvenile specimen of $A$. petersoni in our collection (Fig. 3), perhaps some of the younger specimens collected by Appy and Dadswell also lacked them. In addition, ventrolateral body spines can be overlooked quite easily because of their small size and, in poorly fixed specimens, these spines may be lost because the thin margins of the body seem to be especially vulnerable to autolysis, which can result in the subsequent detachment of the spines. The specimens of Appy and Dadswell (1978) from the sturgeon remain unidentified, and not yet ready to be described, because no adult aporocotylid material from a shortnose sturgeon has been reported or examined by us. We suspect that it represents a species distinct from A. petersoni. As previously stated, the morphological features of the species certainly indicate that it belongs in Acipensericola, but its host's phylogenetic affiliation (Acipenseridae rather than Polyodontidae) and geographic distribution (New Brunswick River draining to northwestern Atlantic Ocean rather than the Mississippi River drainage) suggest that it represents a new species. Addressing this taxonomic problem should require detailed necropsies of freshly killed, wild-caught shortnose sturgeons. Unfortunately, such an opportunity is rare and has proven logistically difficult for us to arrange because the shortnose sturgeon, like nearly all sturgeon species, is presently protected throughout its range.

Collectively, aporocotylids exhibit several different morphological types of suckers associated with the mouth (Bullard and Overstreet, 2003), and we think that the fine features associated with these various types of suckers help elucidate evolutionary relationships within the group. Hereinafter, we refer to them as 
"anterior suckers." The shape of the sucker, the spines of the sucker, and the location of the mouth are diagnostic for at least some genera, e.g., Elaphrobates Bullard and Overstreet, 2003. Homology of these various anterior suckers presently is uncertain for some taxa, which represents a barrier to understanding the phylogenetic interrelationships among aporocotylid genera. Demonstrating homology of these various suckers is beyond the scope of the present paper because it requires a complete phylogenetic analysis of the family; however, we regard the anterior suckers of $A$. petersoni and $P$. yamagutii as 2 slightly different variations of the same homologous sucker type, and we herein delineate that type from those of other aporocotylids by its general shape and the relative position of the mouth. In Acipensericola and Paracardicoloides, unlike all other accepted aporocotylid genera, the anterior sucker is bowl-like, centered on the mouth, and demarcated from the anterior body end by a short trunk or peduncle that supports the sucker and can direct it anteroventrally (Figs. 1, 25; Fig. 3 of Martin [1974]). Despite these general similarities, the pharynx and spination associated with the anterior sucker differs among the species of Acipensericola and Paracardicoloides. The anterior sucker of A. petersoni has spines on its inner anteroventral surface only and is accompanied by a muscular pharynx, whereas that of $P . y a$ magutii reportedly lacks exposed spines and an associated pharynx. The bowl-shaped anterior sucker of Acipensericola and Paracardicoloides is superficially like that of a spirorchiid because it is relatively large and centered on the mouth, but these aporocotylid genera have a peduncle associated with the sucker. In contrast, the spirorchiids studied by 1 of us (S.A.B.) have a sucker that is more strongly muscular and wholly invested in the forebody; there is no obvious peduncle or demarcation between the sucker and body-proper that can be discerned from fixed, stained whole mounts. Based on this feature, we suspect that the anterior sucker ("oral sucker") of spirorchiids (Platt, 2002) is not readily comparable to that of Acipensericola and Paracardicoloides.

Our understanding of the phylogenetic interrelationships of aporocotylids remains unclear because no clade-based phylogenetic hypothesis involving morphological or molecular sequence data for the majority of aporocotylid genera has been published. Two obvious obstacles to completing such a task are that (1) several of the most specious aporocotylid genera need revision, e.g., Aporocotyle Odhner, 1900, Cardicola Short, 1953, and Sanguinicola Plehn, 1905, and (2) type material for many of the named species in those genera are in poor condition or not available to borrow. Although a taxonomic revision and phylogenetic analysis of Aporocotylidae are in preparation by 1 of us (S.A.B.), additional descriptions of new aporocotylid species that infect fishes belonging to previously undocumented host lineages promise to further advance our knowledge of how these flukes evolved among various lineages of "fish." The results of the present study offer some preliminary insight into the potential interrelationships among particular aporocotylid genera and their host groups and provide a framework from which to test future hypotheses about aporocotylid-fish co-phylogeny. For example, the morphological similarities we observed between $A$. petersoni and those aporocotylids that infect non-euteleost fishes indicate a strong phylogenetic affiliation among these genera. Further, the available SSU data indicate that non-euteleost aporocotylids are basal to those that infect euteleosts (Fig. 29). This preliminary result contradicts the notion that fish blood flukes lack a detectable level of phylogenetic host specificity to their definitive hosts.

\section{ACKNOWLEDGMENTS}

We thank Thomas Platt (St. Mary's College, Notre Dame, Indiana) for graciously providing the specimens representing species of Spirorchis MacCallum, 1919, Carettacola Manter and Larson, 1950, Learedius Price, 1934, Hapalotrema Looss, 1899, Monticellius Mehra, 1939, Amphiorchis Price, 1934, and Vasotrema Stunkard, 1928, that helped us gain an appreciation for the oral sucker(s) of spirorchiids. We thank Jody Peterson of the Gulf Coast Research Laboratory (GCRL) for helping collect aporocotylids from paddlefishes in the Mississippi Delta; Ricky Campbell (United States Fish and Wildlife Service, Private John Allen National Fish Hatchery) and Dan O'Keefe (Mississippi State University, College of Forest Resources) for helping locate and capture paddlefishes; Eric Hoberg and Pat Pilitt (United States National Parasite Collection) for providing voucher specimens; and Catherine Schloss, Joyce Shaw, and Margorie Williams (all Gunter Library, GCRL) for providing library assistance. National Science Foundation Grants 0508856, 0529684, and 0608603 supported this work.

\section{LITERATURE CITED}

Appy, R. G., AND M. J. Dadswell. 1978. Parasites of Acipenser brevirostrum LeSueur and Acipenser oxyrhynchus Mitchill (Osteichthyes: Acipenseridae) in the Saint John River Estuary, N. B., with a description of Caballeronema pseudoargumentosus $\mathrm{sp} . \mathrm{n}$. (Nematoda: Spirurida). Canadian Journal of Zoology 56: 13821391.

Bullard, S. A., And R. M. Overstreet. 2002. Potential pathological effects of blood flukes (Digenea: Sanguinicolidae) on pen-reared marine fishes. Proceedings of the Gulf and Caribbean Fisheries Institute 53: 10-25.

, AND 2003 . Elaphrobates euzeti gen. and sp. n. (Digenea: Sanguinicolidae) from snappers (Lutjanidae) in the Gulf of Mexico. In Taxonomy, ecology and evolution of metazoan parasites. (Livre hommage à Louis Euzet), C. Combes and J. Jourdane (eds.). Les Presses Universitaires de Perpignan, Perpignan, France, p. 97-113.

, AND - 2004. Two new species of Cardicola Short, 1952 (Digenea: Sanguinicolidae) from the heart of drums (Sciaenidae) in the Northern Gulf of Mexico. Journal of Parasitology 90: 128136.

$\longrightarrow$, AND J. K. CARLson. 2006. Selachohemecus benzi $\mathrm{n}$. sp. (Digenea: Sanguinicolidae) from the blacktip shark Carcharhinus limbatus in the Northern Gulf of Mexico. Systematic Parasitology 63: 143-154.

Felsenstein, J. 1985. Confidence limits on phylogenies: An approach using the bootstrap. Evolution 39: 783-791.

Grande, L., AND W. E. BEMIS. 1996. Interrelationships of Acipenseriformes, with comments on 'Chondrostei.' In Interrelationships of fishes, M. L. J. Stiassny, L. R. Parenti, and G. D. Johnson (eds.). Academic Press Inc., San Diego, California, p. 9-34.

Khalil, L. F. 2002. Family Schistosomatidae Stiles and Hassal, 1898. In Keys to the Trematoda, Vol. 1, D. I. Gibson, A. Jones, and R. A. Bray (eds.). CABI Publishing and The Natural History Museum, London, England, U.K., p. 419-432.

LitTlewood, D. T. J., AND P. D. Olson. 2001. Small subunit rDNA and the Platyhelminthes: Signal, noise, conflict and compromise. In Interrelationships of the Platyhelminthes, D. T. J. Littlewood, and R. A. Bray (eds.). Taylor and Francis, London, U.K., p. 262-278.

Maddison, D. R., AND W. P. MAdDison. 2003. MacClade 4: Analysis of phylogeny and character evolution. Sinauer, Sunderland, Massachusetts.

MADHAVI, R., AND K. H. RAO. 1970. Orchispirium heterovitellatum gen. et sp. nov. (Trematoda: Sanguinicolidae) from the ray fish, Dasyatis imbricatus Day, from Bay of Bengal. Journal of Parasitology 56: 41-43.

MaillaRd, C., AND M. H. KTARI. 1978. Hyperandrotrema cetorhini $\mathrm{n}$. g., n. sp. (Trematoda, Sanguinicolidae) parasite du système circu- 
latoire de Cetorhinus maximus (Selacii). Annales de Parasitologie Humane et Compare 53: 359-365.

Martin, W. E. 1974. Paracardicoloides yamagutii gen. et sp. n. from an Australian Eel (Trematoda: Sanguinicolidae). Proceedings of the Helminthological Society of Washington 41: 22-25.

Nelson, J. S. 2006. Fishes of the world, 4th ed. John Wiley and Sons, Inc., New York, New York, 601 p.

Nolan, M. J., AND T. H. CRIBb. 2004. The life cycle of Paracardicoloides yamagutii Martin, 1974 (Digenea: Sanguinicolidae). Folia Parasitologica 51: 320-326.

Platt, T. R. 2002. Family Spirorchiidae Stunkard, 1921. In Keys to the Trematoda, Vol. 1, D. I. Gibson, A. Jones, and R. A. Bray (eds.). CABI Publishing and The Natural History Museum, Wallingford, U.K., p. 453-467.

Sмiтh, J. W. 1997a. The blood flukes (Digenea: Sanguinicolidae and Spirorchidae) of cold-blooded vertebrates: Part 1. A review of the published literature since 1971, and bibliography. Helminthological Abstracts 66: 255-294.

1997b. The blood flukes (Digenea: Sanguinicolidae and Spirorchidae) of cold-blooded vertebrates: Part 2. Appendix I: Comprehensive parasite-host list; Appendix II: Comprehensive host-parasite list. Helminthological Abstracts 66: 329-344.
2002. Family Sanguinicolidae von Graff, 1907. In Keys to the Trematoda, Vol. 1, D. I. Gibson, A. Jones, and R. A. Bray (eds.). CABI Publishing and The Natural History Museum, Wallingford, U.K., p. 433-452.

SNYDER, S. D. 2004. Phylogeny and paraphyly among tetrapod blood flukes (Digenea: Schistosomatidae and Spirorchiidae). International Journal for Parasitology 34: 1385-1392.

StunKard, H. W. 1921. Notes on North American blood flukes. American Museum Novitates 12: 1-5.

Swofford, D. L. 2001. PAUP*: Phylogenetic Analysis Using Parsimony (and other methods), Version 4.0b10. Sinauer, Sunderland, Massachusetts.

Thompson, J. D., D. G. Higgins, and T. J. Gibson. 1994. CluStAL W: Improving the sensitivity of progressive multiple sequence alignment through sequence weighting, positions-specific gap penalties and weight matrix choice. Nucleic Acids Research 22: 4673 4680.

VAN DER LAND, J. 1967. A new blood fluke (Trematoda) from Chimaera monstrosa L. Proceedings K. Nederlandse Akademie van Wtenschappen, Section C, Biological and Medical Sciences 70: 110120. 